\title{
A comparison of serum potassium level between high dose and low dose of Succinylcholine
}

\author{
R K Yadav, ${ }^{1}$ P C Majhi, ${ }^{2}$ D Tiwari ${ }^{3}$
}

${ }^{1}$ Assistant Professor, ${ }^{2}$ Professor and Head, ${ }^{3}$ Lecturer, Department of Anaesthesiology, College of Medical Sciences-Teaching Hospital, Bharatpur, Chitwan,Nepal.

\section{Abstract}

Aims

Succinylcholine is a depolarizing type of neuromuscular blocking drug. Aim of this study is to evaluate and compare serum potassium level with upper dose limit of succinylcholine $(1.5 \mathrm{mg} / \mathrm{kg})$, which is used normally in anesthetic practice with low dose of succinylcholine $(0.5 \mathrm{mg} / \mathrm{kg})$.

\section{Materials and methods}

A total of 100 patients attending for elective surgery in College of Medical Sciences -Teaching Hospital( CMSTH)), Bharatpur, Chitwan, Nepal were studied. Two blood samples were collected, one before surgery and another at 4 min after injection of succinylcholine and send to central lab for estimation of serum potassium level.

\section{Result}

The serum potassium levels recorded during the study showed that there were neither significant differences observed within the groups nor was there any difference between the groups.

\section{Conclusion}

In absence of pathological conditions related to raised serum potassium level, both high and low doses of succinylcholine can be used safely as there is no statistically significant differences in serum potassium level between high and low dose of succinylcholine.

\section{Introduction}

Succinylcholine is a depolarizing muscle relaxant most commonly used during rapid sequence intubation due to its rapid and short duration of action. It produces adequate intubating conditions within 30-40 seconds. With these features, succinylcholine seems to be appropriate relaxant in various clinical settings. ${ }^{1}$

Correspondence: Dr. R.K.Yadav

Email: drrajeshyadav@yahoo.com
Succinylcholine is associated with a large number of undesirable side effects, the notable one being hyperkalemia which may lead to cardiac arrhythmias, bradycardia. These undesirable effects have prompted anesthesiologists to restrict the use of succinylcholine. Usual intravenous dose of succinylcholine is $1-1.5 \mathrm{mg} /$ $\mathrm{kg}$ of body weight ${ }^{2}$ and many of the side effects have 
been seen to be dose related. This has also been hypothesized by waters and mapleson. ${ }^{3}$

In addition, changes in potassium level seems to be directly related to dose of succinylcholine used. Various hypothesis put forward by waters and collier ${ }^{4}$ suggest altered balance of forces which develop at muscle fibre fascia interface or at sarcolemmal membrane, resulting in damage to motor units thereby causing hyperkalemia, myoglobinuria, creatine phosphokinasuria etc. Dose of succinylcholine used plays an important role as it determines the amount of drug reaching neuromuscular junction finally.

Thus, there is adequate evidence to believe succinylcholine in low doses would have fewer incidences of hyperkalemia. The present study is aimed to compare the serum potassium level between high and low dose of succinylcholine with special reference to intubation.

\section{Material and methods}

This prospective study was carried out from Jan. 2012 to Dec. 2012. A total of 100 patients were enrolled in study after taking informed consent. All patients who were selected were scheduled for various surgeries like General surgery, Orthopaedic surgery and Gynaecological surgery in CMS-Teaching Hospital, Bharatpur, Chitwan, Nepal. All the patients were in the age group 15-45 years and belonged to ASA grade I or II. All these patients on preoperative clinical evaluation were assessed to have adequate airway and belonged to class I or II of Mallampati classification. ${ }^{5}$ Those patients having class III or IV airways were not included.

All the patients were randomly allocated in two groups:
1. Group I: Fifty patients belonging to this group were administered $0.5 \mathrm{mg} / \mathrm{kg}$ of Succinylcholine.

2. Group II: Remaining 50 patients were administered Succinylcholine in a dose of $1.5 \mathrm{mg} /$ $\mathrm{kg}$.

A standard anesthetic technique was used in all these patients. All patients were premeditated with diazepam $0.02 \mathrm{mg} / \mathrm{kg}$ in the night prior to surgery and in the morning on the day of surgery. The serum potassium level was also evaluated in the morning just before surgery to know the base line value of serum potassium for that particular individual. On the table an intravenous line using normal saline was started and monitor was attached for blood pressure, heart rate, $\mathrm{spo}_{2}$ ECG monitoring. Induction of anesthesia was achieved with inj.Thiopentone upto a maximum of $5 \mathrm{mg} / \mathrm{kg}$ given over 20-30 seconds. After further 30 seconds, appropriate dose of Succinylcholine $0.5 \mathrm{mg} / \mathrm{kg}$ or $1.5 \mathrm{mg} / \mathrm{kg}$ depending upon the group the patient belonged to, was given. Thereafter anesthesia was maintained using oxygen, nitrous oxide, halothane and long acting relaxants wherever indicated. Blood sample was collected at $4 \mathrm{~min}$ after injection of succinylcholine for estimation and comparision of serum potassium levels.

\section{Statistical analysis}

Data was analyzed by $\mathrm{Z}$ test. Comparison within the group for serum potassium was done using students paired ' $\mathrm{t}$ ' test. For comparison between the two multiple linear regression analysis was undertaken controlling for baseline variables. The consolidated results of these analyses have been presented in appendix. Statistical significance was taken as $\mathrm{p}<0.05$. 
R K Yadav et al, A comparasion of serum potassium level.

\section{Results}

Total of 100 patients were studied in both groups, fifty belonging to low dose group I and fifty in high dose group II. All patients were of ASA I or II status.

Demographic data are presented in tables 1,2,3. Mean age in group was 28.84 (8.58) years as against 29.42 (8.72) years in group II. On analysis the difference between two groups was not significant $(p<0.74)$. Mean weight in group I was 48.02 (9.23) whereas in group II it was 46.78 (10.08). The difference was again insignificant $(<0.529)$ indicating successful randomization. Types of surgery included abdominal tubectomy, laparoscopies, amputation, reshaping of stump, hydrocele, phimosis etc.

Table 1: mean age (in years)

\begin{tabular}{ccc}
\hline Group & No. of cases & Mean (SD) \\
\hline I & 50 & $28.84(8.58)$ \\
II & 50 & $29.42(8.72)$ \\
\hline
\end{tabular}

Table 2: sex distribution

\begin{tabular}{lccc}
\hline Group & $\begin{array}{c}\text { No. of } \\
\text { cases }\end{array}$ & $\begin{array}{c}\text { Male } \\
(\boldsymbol{\%})\end{array}$ & $\begin{array}{c}\text { Female } \\
(\boldsymbol{\%})\end{array}$ \\
\hline I & 50 & $23(46)$ & $27(54)$ \\
II & 50 & $24(48)$ & $26(52)$ \\
\hline
\end{tabular}

Table 3: mean weight (kg)

\begin{tabular}{ccc}
\hline Group & No of cases & Mean (SD) \\
\hline I & 50 & $48.02(9.23)$ \\
II & 50 & $46.78(10.08)$ \\
\hline
\end{tabular}

Changes, in serum potassium levels as recorded during the study have been presented in table 4 . There were no significant differences observed within the groups nor was there any difference between the groups.

Table 4: changes in plasma potassium concentration before and after Succinylcholine: values as mean (SD) $\mathrm{mEq} / \mathrm{L}$

\begin{tabular}{ccc}
\hline Group & $\begin{array}{c}\text { Before } \\
\text { surgery }\end{array}$ & $\begin{array}{c}\text { 4 minutes after } \\
\text { Succinylcholine }\end{array}$ \\
\hline I & $3.89(0.37)$ & $3.90(0.39)$ \\
II & $4.01(0.27)$ & $4.04(0.30)$ \\
\hline
\end{tabular}

\section{Discussion}

Hyperkalemia following Succinylcholine was first describe by Klupp (1954) and later by Paton (1959). ${ }^{6}$ Weintraub et al in their study observed a dose response relationship between succinylcholine and elevation in serum potassium level. The $40 \mathrm{mg}$ dose of Succinylcholine was associated with smaller and less prolonged elevation in potassium when compared with $100 \mathrm{mg}$ dose. ${ }^{7}$ Similar results were also demonstrated by Stoelting. ${ }^{8}$ In present study no such trend was observed either in low dose or high dose group and differences observed were statistically insignificant (table 4).

This could be explained by several reasons. Plasma potassium levels closely follow blood gas changes. Though efforts based on clinical grounds were made to ensure normocapnia there was no objective monitoring of blood gases values as was done by Weintraub et al. ${ }^{7}$ In their cases an arterial catheter was placed for sampling. Secondly in this study control values of serum potassium were taken to be those obtained in morning prior to surgery. Thiopentone along 
with other intravenous induction agents can cause alteration in plasma electrolyte level. Bali et al demonstrated a mean fall of $0.24(0.051) \mathrm{mEq} / \mathrm{L}$ in potassium levels. Seventeen out of twenty patients showed a reduction in potassium levels following $5 \mathrm{mg} /$ $\mathrm{kg}$ of thiopentone. All readings were also noticed to return to control limits within 10 minutes. ${ }^{9}$

In addition hyperkalemia following depolarizing neuromuscular blockers has been seen to reach a peak between one and seven minutes. ${ }^{7}$ Most commonly at 3 minutes.${ }^{4}$ Samples were collected only at 4 minutes after administration of Succinylcholine and therefore it is possible that potassium levels might have started to return to pre-relaxant value.

\section{Conclusion}

Succinylcholine can be used in lower doses $(0.5 \mathrm{mg} /$ $\mathrm{kg}$ ) or higher doses $(1.5 \mathrm{mg} / \mathrm{kg})$ in elective cases without much alteration in serum potassium level.

\section{References}

1. Schwarz S,Ilias W, Lackner F, et al. rapid trachel intubation with vecuronium. The priming principle. Anesthesiology 1985;62:388-93.

2. Froancois Donati and David R. Brevan. Neuromuscular Blocking Agent In: P.G.Barash,
B.F.Cullen, R.K.Stoelting. Clinical Anesthesia, $5^{\text {th }}$ ed.Philadelphia:Lippincott Williams and Wilkins; 2006. 427.

3. Waters DJ, Mapleson WW. Suxamethonium pains and observation. Anesthesia 1971;26:127-41.

4. Collier CB. Suxamethonium pains and early electrolyte changes. Anesthesia 1978; 33:454.

5. Mallampatti SR, Galt SP, Gugino LD, et al. A clinical sigh to predict difficult intubation : a prospective study. Can Anesth Society Journal 1985;32: 429-34.

6. Paton WDM.Mode of action of nueromuscular blocking agent. Brit J Anesth 1955;28:470.

7. Weintraub HD, Heisterkamp DV, Cooperman LH. Changes in plasma potassium concerntrationafterb depolarizing block in anesthetized man. Brit J Anaes 1969;41:1048-52.

8. Beretervide KU. Action of succinylcholine chloride on circulation. Brit J Pharmacol 1955;10:265.

9. Bali IM, Dundee JW. Immidiate changes in plasma potassium, sodium and chloride induced by intravenous induction agents. Brit J Anaes 1974; 46: 929. 